\title{
Incomplete renal tubular acidosis as a predisposing factor for calcium phosphate stones in neuropathic bladder: a case report Subramanian Vaidyanathan ${ }^{* 1}$, Bakul M Soni ${ }^{1}$, Ian D Watson ${ }^{2}$, Gurpreet Singh ${ }^{3}$, Peter L Hughes ${ }^{4}$ and Paul Mansour ${ }^{5}$
}

\author{
Address: ${ }^{1}$ Regional Spinal Injuries Centre, District General Hospital, Southport, PR8 6PN, UK, ${ }^{2}$ Department of Clinical Biochemistry, District \\ General Hospital, Southport, PR8 6PN, UK, ${ }^{3}$ Department of Urology, District General Hospital, Southport, PR8 6PN, UK, ${ }^{4}$ Department of \\ Radiology, District General Hospital, Southport, PR8 6PN, UK and ${ }^{5}$ Department of Cellular Pathology, District General Hospital, Southport, PR8 \\ 6PN, UK \\ Email: Subramanian Vaidyanathan* - S.Vaidyanathan@southportandormskirk.nhs.uk; \\ Bakul M Soni - Bakul.Soni@southportandormskirk.nhs.uk; Ian D Watson - Ian.Watson@southportandormskirk.nhs.uk; \\ Gurpreet Singh - Gurpreet.Singh@southportandormskirk.nhs.uk; Peter L Hughes - Peter.Hughes@southportandormskirk.nhs.uk; \\ Paul Mansour - Paul.Mansour@southportandormskirk.nhs.uk \\ * Corresponding author
}

Published: 17 November 2008

Cases Journal 2008, 1:318 doi:10.1186/1757-1626-1-318

This article is available from: http://www.casesjournal.com/content/I/I/3/8

(C) 2008 Vaidyanathan et al; licensee BioMed Central Ltd.

This is an Open Access article distributed under the terms of the Creative Commons Attribution License (http://creativecommons.org/licenses/by/2.0), which permits unrestricted use, distribution, and reproduction in any medium, provided the original work is properly cited.
Received: 23 August 2008

Accepted: 17 November 2008

\begin{abstract}
We present a male tetraplegic patient, who developed stones in neuropathic bladder six times within a span of three years. Unusual features of this case are: (I) This patient started developing stones in urinary bladder thirteen years after sustaining spinal cord injury. (2) He was performing intermittent catheterisation and did not have an indwelling catheter. (3) The presenting symptom of vesical lithiasis was abdominal spasms and not urine infection. (4) The major component of the stones was calcium phosphate; magnesium ammonium phosphate was completely absent in the calculus on four occasions. (5) Proteus species were not grown from urine at any time. (6) This patient failed to acidify urine below a pH of 5.3 after taking simultaneously furosemide $(40 \mathrm{mg})$ and fludrocortrisone ( $\mathrm{I} \mathrm{mg}$ ), which suggested incomplete renal tubular acidosis type $\mathrm{I}$.

We learn from this case that biochemical analysis of stones removed from urinary bladder may be useful. If the major component of vesical calculus is calcium phosphate, complete or incomplete renal tubular acidosis type I should be excluded, as it may be possible to reduce the risk of recurrence of calcium phosphate stones by oral potassium citrate therapy or, vegetable and fruit rich diet.
\end{abstract}

\section{Background}

A study of bladder calculi in 500 persons treated at the University of Alabama in Birmingham Spinal Cord Injury Care System between 1973 and 1981 showed that bladder calculi were most likely to develop within one year of spinal cord injury. Patients developing bladder calculi prior to first definitive discharge were most likely to have neurologically complete lesions and Klebsiella infections at admission. Patients developing bladder stones within two years of hospital discharge were most likely to have indwelling urethral catheters and either Proteus or multipleorganism infections at discharge. [1] Thus indwelling urinary catheter and urine infections are major risk factors for vesical calculi in spinal cord injury patients. Patients, who develop vesical calculi, often present with catheter blockages or urine infections. These stones usually con- 
tain magnesium ammonium phosphate. When a spinal cord injury patient develops recurrent urine infections and vesical calculi, squamous metaplasia may be seen in the neuropathic bladder. Spinal cord injury patients, who develop recurrent nephrolithiasis, are advised to undergo biochemical evaluation, but patients with vesical calculi do not usually receive such advice, as metabolic abnormalities are uncommon in those who form stones only in the urinary bladder. Similarly, dietary modification or oral citrate therapy is recommended to patients with calcium phosphate kidney stones and not for those with bladder stones.

We report an adult male patient with tetraplegia, who developed recurrent bladder calculi. This case had several unusual features. The presenting symptom of vesical calculus was abdominal spasm. This patient was performing intermittent catheterisations and did not have long-term catheter drainage. He started developing bladder stones thirteen years after sustaining spinal cord injury. The major component of vesical calculi was calcium phosphate. Renal acidification test revealed incomplete renal tubular acidosis type 1 .

\section{Case presentation}

A Caucasian male, born in 1943, sustained fracture dislocation of seventh cervical and first thoracic vertebrae with tetraplegia in 1992, when he lost control of motorbike. Internal fixation and fusion of cervico-dorsal junction was performed. He was managing his bladder by a penile sheath. In 1997, this person was taught the technique of self-catheterisation. He started performing intermittent catheterisations.

Intravenous urography was performed as a routine test on 06 August 1997, and it showed marked prostatic calcification. Kidneys, ureters and bladder were normal. Intravenous urography was performed during a routine followup on 30 June 1999; and no radio opaque calculi were seen. Both kidneys excreted the contrast; normal kidney, pelvicalyceal systems, ureters and bladder. As the patient developed frequent urine infections, intravenous urography was performed on 31 January 2000. No radio opaque renal or vesical calculi were seen; prostatic calcification was present. Both kidneys excreted contrast; normal kidneys, pelvicalyceal system, ureters and bladder. There was no significant residual urine.

In September 2004, this person developed spasms of abdomen, cold sweats and headache. He was moving his bowels every day in the evening and was using Carbalax suppositories. Intravenous urography was performed on 05 November 2004. Kidneys and ureters were normal. Multiple diverticula arising from the bladder were noted.

This patient attended spinal unit on 24 January 2005 with spasm of abdomen. Chest X-ray, which was taken on 04 March 2005, showed clear lungs. X-ray of abdomen revealed moderate faceal loading of the colon. Ultrasound scan of abdomen showed multiple gallstones; common bile duct was not dilated. Ultrasound examination of urinary tract revealed a simple cyst in the upper pole of right kidney; no renal calculi; no renal scarring or hydronephrosis. There was a calculus in the urinary bladder. Intravenous urography revealed prostatic calcification and a vesical calculus. (Figure 1) Pelvicalyceal systems and ureters were normal. Diverticula were seen in the bladder. (Figure 2) On 18 November 2005, this person underwent external urethral meatotomy, cystoscopy and elctrohydrualic lithotripsy of vesical calculi. (Table 1) Following removal of stones from urinary bladder, spasm of abdomen disappeared and this person could sleep during night.

In August 2006, he developed severe spasms in the stomach. X-ray of abdomen revealed several calculi in urinary bladder. (Figure 3) Cystoscopy and electrohydraulic lithotripsy were carried out on 08 December 2006. (Table 1) In May 2007, he developed spasms of abdomen once again. Not surprisingly, X-ray of abdomen showed several stones in urinary bladder. (Figure 4) Electrohydraulic lithotripsy was carried out on 18 May 2007. The stones were very hard to break. This observation, which was made during lithotripsy, corroborated with the biochemical analysis of the stone. (Table 2) The stone was found to contain $100 \%$ calcium phosphate.

Table I: List of dates when cystoscopy and electrohydraulic lithotripsy of vesical calculi were performed

\begin{tabular}{|c|c|}
\hline Date & Procedure \\
\hline I8 November 2005 & $\begin{array}{l}\text { Tight external urethral meatus: meatotomy was performed with Otis urethrotome. Electrohydrualic lithotripsy of vesical } \\
\text { calculi was carried out. Fragments of stones were removed completely. }\end{array}$ \\
\hline 08 December 2006 & Electrohydrualic lithotripsy of vesical calculi was carried out. Fragments of stones were removed completely. \\
\hline 18 May 2007 & Electrohydrualic lithotripsy of vesical calculi was carried out. Fragments of stones were removed completely. \\
\hline 02 November 2007 & Electrohydrualic lithotripsy of vesical calculi was carried out. Fragments of stones were removed completely. \\
\hline I8 April 2008 & Electrohydrualic lithotripsy of vesical calculi was carried out. Fragments of stones were removed completely. \\
\hline 27 June 2008 & Electrohydrualic lithotripsy of vesical calculi was carried out. Fragments of stones were removed completely. \\
\hline
\end{tabular}




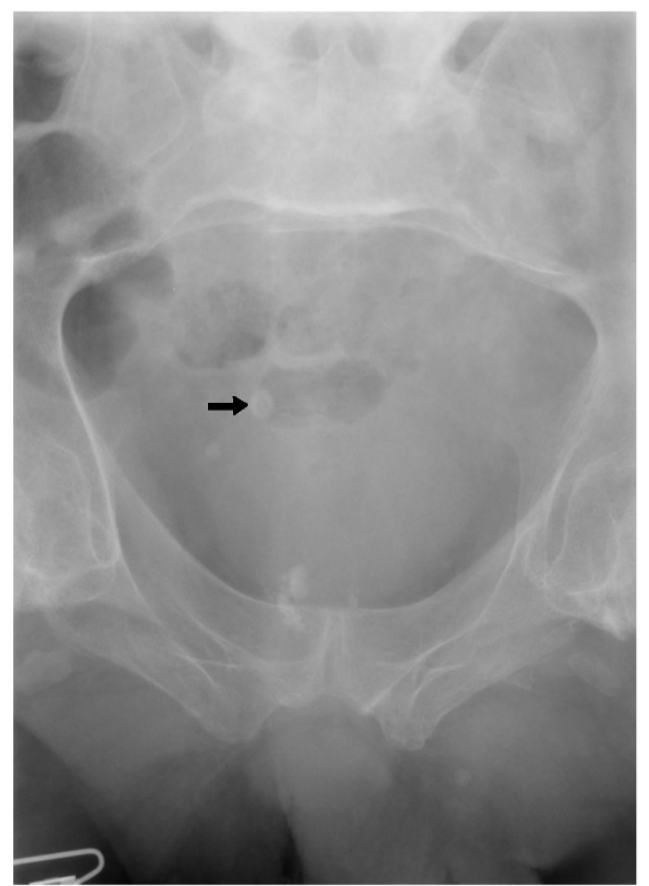

\section{Figure I}

X-ray of urinary bladder taken on 07 March 2005 shows prostatic calcification. There is a radio opaque shadow in the region of urinary bladder, which is probably a vesical calculus (arrow).

This patient again developed spasms of abdomen in September 2007. X-ray of abdomen showed vesical calculi. (Figure 5) Electrohydraulic lithotripsy was performed on 02 November 2007. All fragments of stones were removed from the bladder. Following the procedure, a pressure mark over sacrum was noticed. This was non-blanchable erythema of intact skin, which represented Grade 1 pressure ulcer. The patient was advised to stay in bed and lie on his sides until the pressure mark healed completely.

He attended spinal unit on 26 March 2008 with abdominal spasms. Radiograph of abdomen revealed several vesical calculi. (Figure 6) Electrohydraulic lithotripsy was carried out on 18 April 2008. It was ensured that no piece of stone was left behind in the bladder or in vesical diverticula. He did very well after lithotripsy. But this patient came back on 09 June 2008 with abdominal spasms. Xray of abdomen showed stones in urinary bladder. (Figure 7) Electrohydraulic lithotripsy was performed on 27 June 2008. This patient did well after the sixth operation for removal of recurrent vesical calculi.

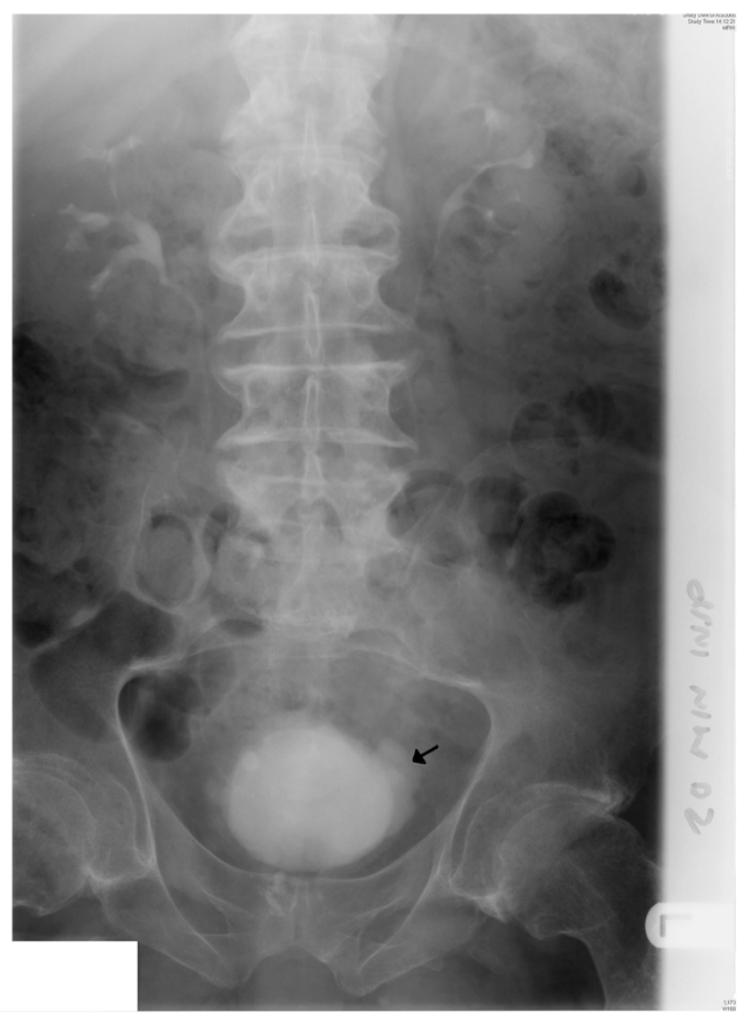

Figure 2

Intravenous urography (07 March 2005): twenty minutes film shows undilated pelvicalyceal systems on both sides; multiple, small diverticulae arise from the urinary bladder (arrow).

Since bladder stone disease is a risk factor for vesical malignancy in patients with spinal cord injury, a sample of urine was sent for cytology. Cytology showed benign epithelial cells; no suspicious or malignant cells were seen. No keratinising squamous cells were identified. (Figures 8 and 9)

This patient performed intermittent catheterisations about six times a day; he preferred ready to use, sterile, pre-lubricated SpeediCath catheters size 12 French (Coloplast Ltd, Peterborough PE2 6FX, United Kingdom) for self-catheterisations because the catheter package already contained water for lubrication and it was user-friendly. With regular intermittent catheterisations, this patient remained continent and was able to discard penile sheath and leg bag. Asymptomatic bacteriuria was observed on several occasions and organisms isolated from urine are listed in Table 3

Since this patient developed repeatedly stones in urinary bladder, we carried out biochemical tests of blood and urine to look for underlying metabolic abnormality, if any. When biochemical tests were carried out, this patient 
Table 2: Results of biochemical analysis of stones, which were removed from urinary bladder: composition of stone is shown in percentage

\begin{tabular}{lllll}
\hline $\begin{array}{l}\text { Date when a sample of calculus } \\
\text { removed from urinary bladder } \\
\text { was received by Biochemistry } \\
\text { Laboratory for analysis }\end{array}$ & $\begin{array}{l}\text { Weight of the specimen } \\
\text { (milligrams) }\end{array}$ & Calcium Oxalate & Calcium Phosphate & $\begin{array}{l}\text { Magnesium ammonium } \\
\text { phosphate }\end{array}$ \\
\hline 21 November 2005 & 64 & Absent & $64 \%$ & $36 \%$ \\
08 December 2006 & 7184 & $6 \%$ & $94 \%$ & Absent \\
18 May 2007 & 5737 & Absent & $100 \%$ & Absent \\
02 November 2007 & 43 & $9 \%$ & $90 \%$ & Absent \\
21 April 2008 & 1149 & Absent & $88 \%$ & Absent \\
27 June 2008 & 87 & $10 \%$ & $90 \%$ &
\end{tabular}

had started taking orange juice in large quantities in the hope of preventing further formation of urinary stones. Results of biochemical tests are given below. Reference range is mentioned within parenthesis.

\section{4-hours urine}

14 November 2005 Urine volume: $1102 \mathrm{~mL}$

14 November 2005 Calcium: 5.08 mmol/day (1.50 2.50)

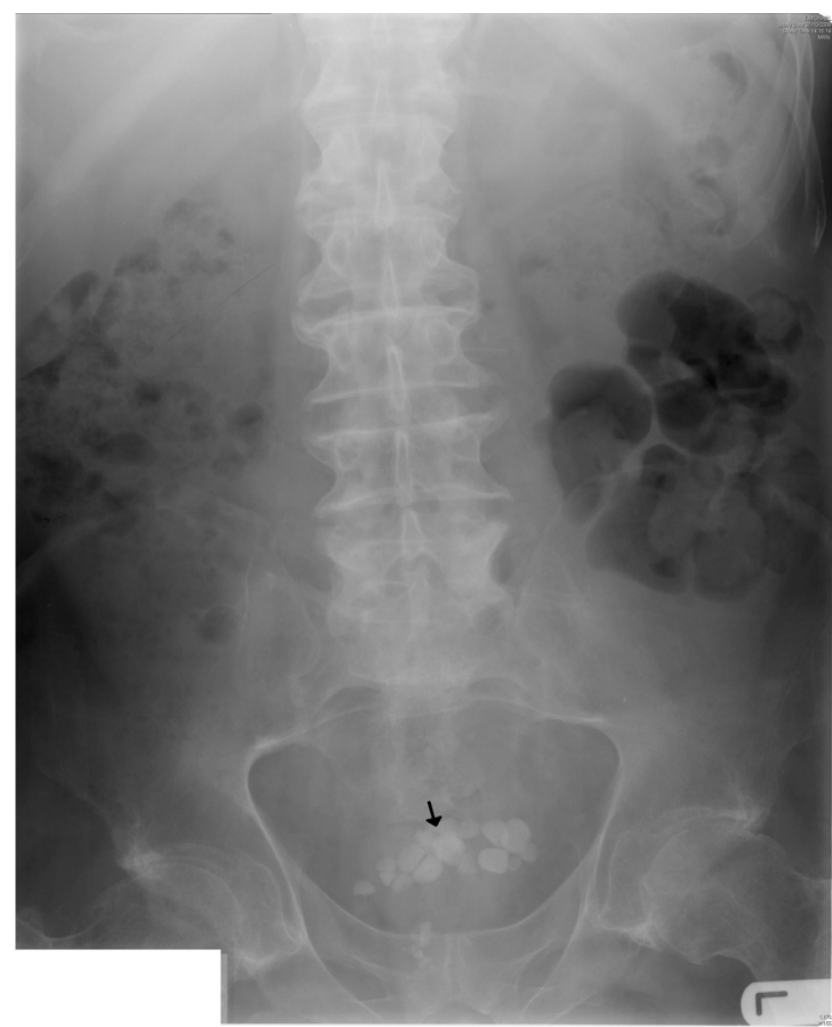

Figure 3

X-ray of abdomen (27 October 2006) reveals several calcified stones in urinary bladder (arrow).
14 November 2005 Urate: $2.97 \mathrm{mmol} /$ day $(1.19$ - 2.98)

14 November 2005 Citrate: $2.18 \mathrm{mmol} / 24$ hours (1.68 6.45)

14 November 2005 Oxalate: 187 umol/day (189 - 477)

16 November 2005 Urine volume: $1120 \mathrm{~mL}$

16 November 2005 Creatinine clearance: $71 \mathrm{~mL} /$ minute

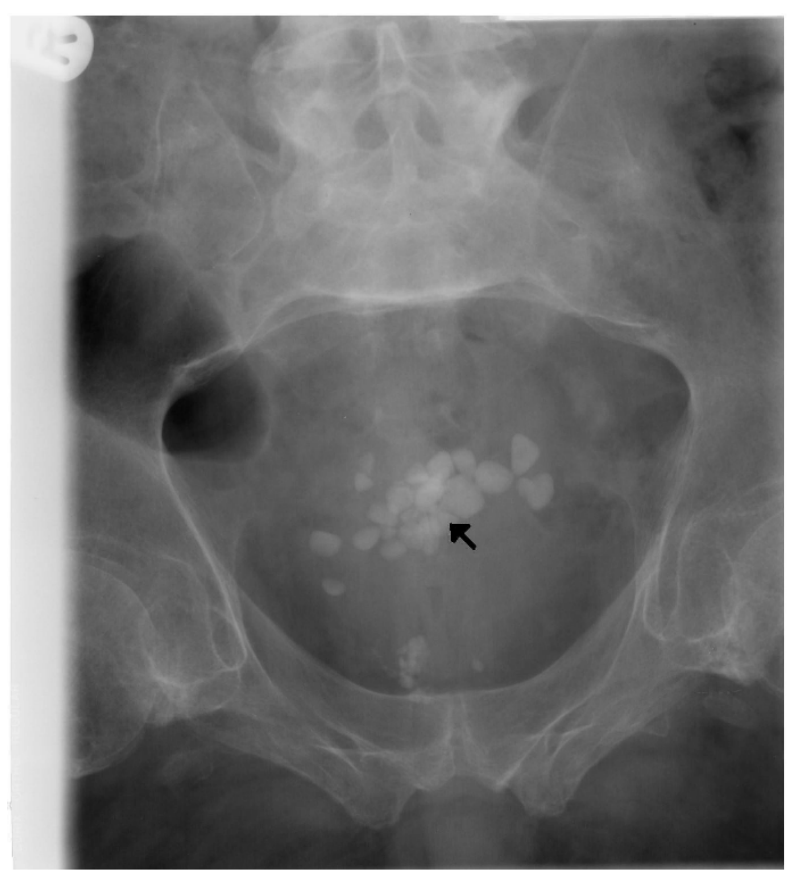

Figure 4

X-ray of urinary bladder taken on I 4 May 2007 shows several vesical calculi (arrow). 


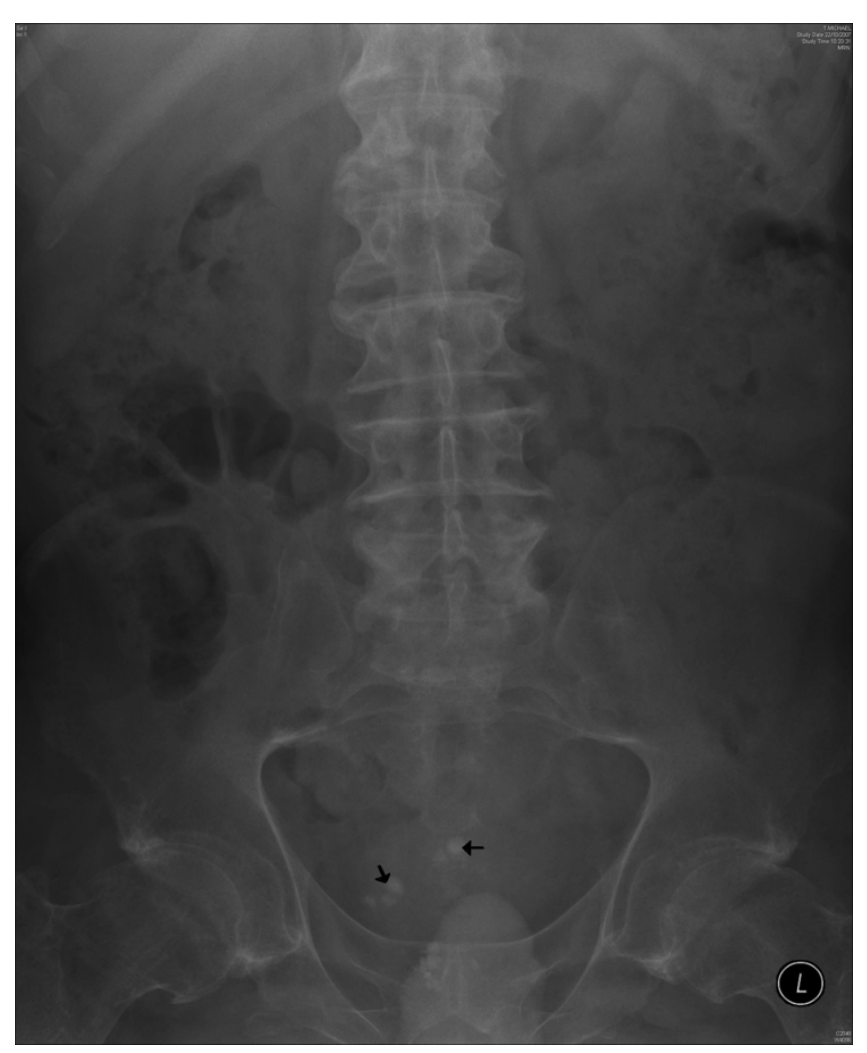

\section{Figure 5}

X-ray of abdomen taken on 22 October 2007 shows the presence of small stones in urinary bladder (arrow).

15 May 2007 Urine volume: 1360 mL

15 May 2007 Calcium:5.47 mmol/day (2.50 - 7.50)

15 May 2007 Phosphate: $20.3 \mathrm{mmol} /$ day (12.9 - 42.0)

15 May 2007 Urate: 1.43 mmol/day $(1.19$ - 2.58)

01 April 2008 Urine volume: $1050 \mathrm{~mL}$

01 April 2008 Oxalate: 312 umol/day (189-477)

01 April 2008 Urate: $0.87 \mathrm{mmol} /$ day (1.19-2.98)

01 April 2008: Calcium: $3.85 \mathrm{mmol} /$ day (2.50-7.50)

09 April 2008 Urine volume: $1244 \mathrm{~mL}$

09 April 2008 Citrate: $2.24 \mathrm{mmol} / 24$ hours (1.68-6.45)

03 June 2008 Urine volume: $1480 \mathrm{~mL}$

03 June 2008 Calcium: $4.53 \mathrm{mmol} /$ day (2.50-7.50)

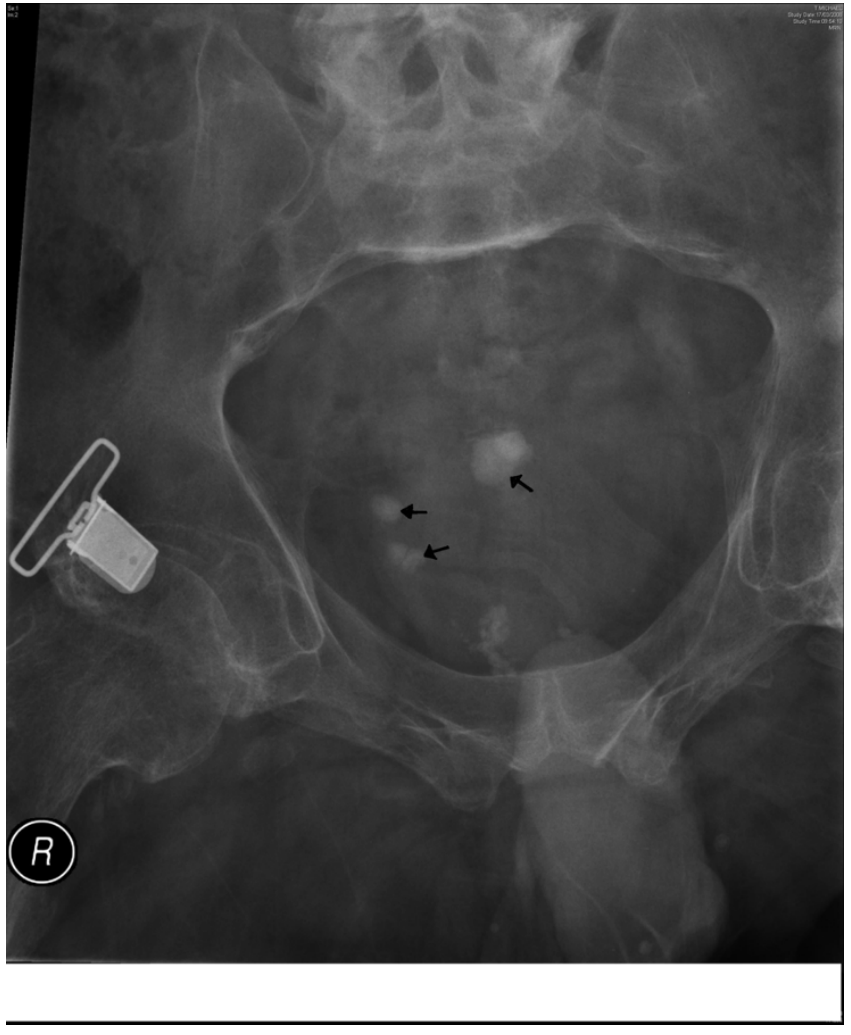

Figure 6

X-ray of urinary bladder ( 17 March 2008) shows four or five small stones (arrow).

03 June 2008 Oxalate: 388 umol/day (189-477)

03 June 2008 Urate: 2.96 umol/day (1.19-2.98)

18 June 2008 Urine volume: 1150 mL

18 June 2008 Calcium: $4.14 \mathrm{mmol} /$ day (2.50-7.50)

18 June 2008 Urate: 0.97 umol/day (1.19-2.98)

08 July 2008 Urine volume: $1860 \mathrm{~mL}$

08 July 2008 Oxalate: 370 umol/day (189-477)

\section{Blood biochemistry}

Calcium: $2.23 \mathrm{mmol} / \mathrm{L}(2.20-2.60)$

Phosphate: $1.01 \mathrm{mmol} / \mathrm{L}(0.80-1.50)$

Alkaline phosphatase: $106 \mathrm{u} / \mathrm{L}$ (40-120)

Sodium: $139 \mathrm{mmol} / \mathrm{L}$ (133-146)

Potassium: $4.3 \mathrm{mmol} / \mathrm{L}(3.5-5.2)$ 


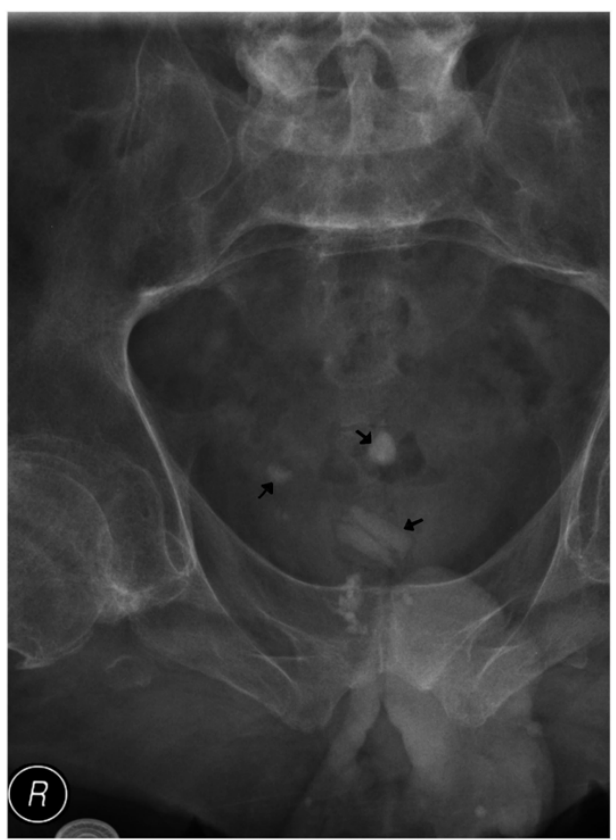

\section{Figure 7}

X-ray of urinary bladder taken on 09 June 2008 reveals one large and two small calculi (arrow).

Chloride: 105 mmol/L (95-110)

Bicarbonate: $34 \mathrm{mmol} / \mathrm{L} \mathrm{(22-30)}$

Magnesium: $0.96 \mathrm{mmol} / \mathrm{L}(0.70-1.00)$

Urea: $6.5 \mathrm{mmol} / \mathrm{L}(3.0-9.0)$

Creatinine: 58 umol/L (0-150)

Urate: $0.20 \mathrm{mmol} / \mathrm{L}(0.00-0.43)$

Random glucose: $6.9 \mathrm{mmol} / \mathrm{L}(3.6-7.8)$

TSH: $2.000 \mathrm{iu} / \mathrm{L}(0.300-5.00)$

Free T 4: $12.4 \mathrm{pmol} / \mathrm{L}(9.0-24.0)$

C-terminal telopeptide:0.32 ng/ml (0.10-0.50)

\section{Urine biochemistry}

Random urine bicarbonate: $2.3 \mathrm{mmol} / \mathrm{L}$

Random urine bicarbonate (12 August 2008): $1.7 \mathrm{mmol} /$ $\mathrm{L}$

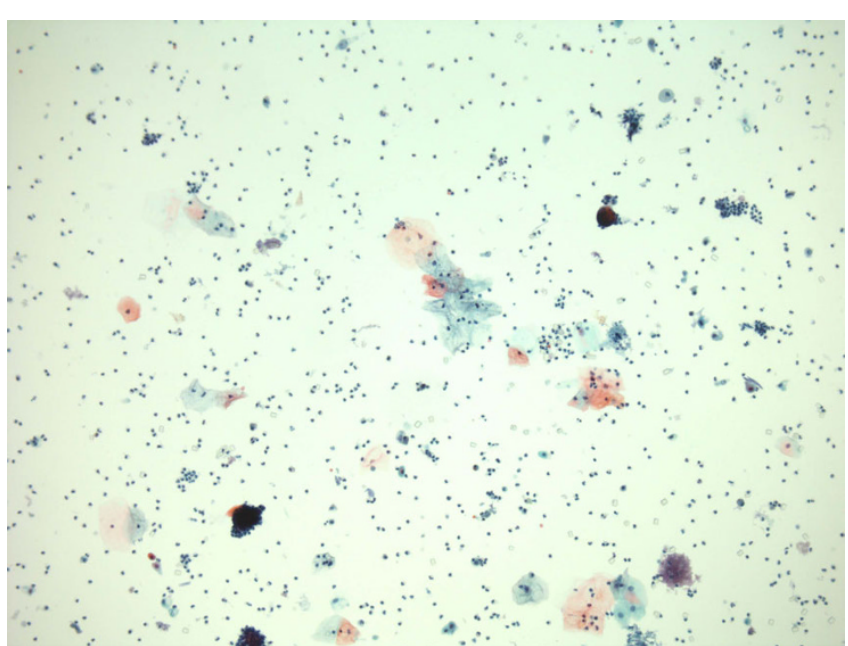

Figure 8

Urine cytology photomicrograph shows benign epithelial cells with a background of neutrophil ploymorphs. (Cytospin preparation, Papanicolau stain).

\section{Urine pH: 6.1}

In summary, this patient had citrate level in urine at the bottom of the reference range. Urine $\mathrm{pH}$ was 6.1 , which would be conducive to calcium phosphate stone formation. We carried out urinary acidification test to look for distal renal tubular acidosis after taking written informed consent from the patient.

Urinary acidification was assessed by simultaneous administration of furosemide $(40 \mathrm{mg})$ and fludrocortisone $(1 \mathrm{mg})$. A baseline urine sample was taken followed by oral administration of furosemide $(40 \mathrm{mg})$ and fludrocortisone $(1 \mathrm{mg})$. Fluid intake was ad libitum. Urine was collected hourly for the next six hours. The results of urine acidification test are given in Table 4 . The minimum $\mathrm{pH}$ value of urine was 5.56, which was noted four hours after ingestion of furosemide and fludrocortisone. Failure to acidify urine to a $\mathrm{pH}$ of less than 5.3 is consistent with incomplete distal renal tubular acidosis.

Therapeutic options were: (1) to prescribe potassium citrate or sodium citrate; (2) to advise the patient to take vegetables and fruits daily. Both potassium citrate and sodium citrate were available on prescription and therefore, the patient did not have to pay for these medicines. But the patient would have to buy fruits, vegetables or fruit juices. We were concerned about the possible side effect of sodium citrate therapy, as supplementation of sodium can potentially affect blood pressure especially when taken for a prolonged period. The patient decided to take more citrus fruits in his diet every day. He was given 


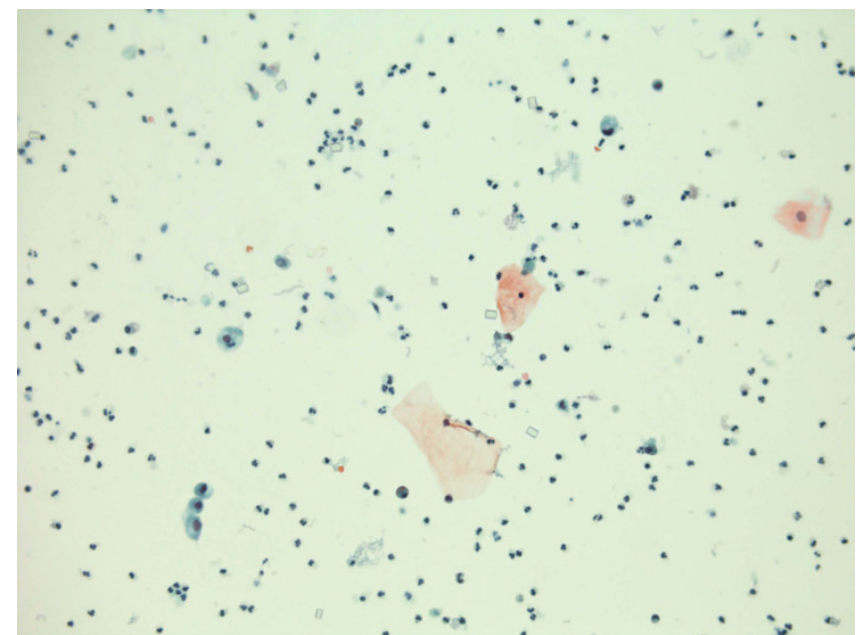

Figure 9

Urine cytology: higher power view shows benign urothelial cells (left middle and left bottom) and squamous cells (middle and middle right). No keratinising squamous cells are present. (Cytospin preparation, Papanicolau stain)

information sheet on citrate content of different fruits and drinks. [2]

\section{Discussion}

A review of the medical records of all veterans with spinal cord injury, who received care in Michael E DeBakey Veterans Affairs Medical center, Houston, Texas, USA from 1 January 2003 to 2 January 2006 [3] revealed that 71 subjects were diagnosed with Proteus in their urine at some point during the study period, and 19 of them (27\%) were also diagnosed with stones $(P=0.045)$. Other organisms associated with the presence of stones included Enterococcus, Klebsiella, Pseudomonas, Morganella, and Providencia ( $P$ $<0.05$ ). In this patient, Proteus was not grown in urine at any time, but this patient had asymptomatic bacteriuria with Escherichia coli, Enterococcus faecalis, Klebsiella aerogenes, and Pseudomonas aeruginosa.

Calcium phosphate calculi in urinary bladder are rare, as magnesium ammonium phosphate, which is associated with urine infection, is the common vesical calculus in patients, who have indwelling catheters. Calcium phosphate stones in kidneys are seen in patients with renal tubular acidosis type 1 . Typically patients with complete renal tubular acidosis type 1 have metabolic acidosis, alkaline urine, decreased urinary citrate, and hypercalcuria. Persons with incomplete renal tubular acidosis type 1 may not markedly manifest any of these abnormalities. Investigation of this patient revealed little that was abnormal, however he was found to have a basal urine $\mathrm{pH}$ of 6.1 , which would be conducive to calcium phosphate cal- culi formation. Therefore, we performed urinary acidification test by simultaneous administration of furosemide (40 mg) and fludrocortisone (1 mg). The short ammonium chloride test, which involves the oral ingestion of a quantity of ammonium chloride and serial measurements of urine $\mathrm{pH}$, is adopted internationally as the 'gold standard' diagnostic test for distal renal tubular acidosis. However, although the ammonium chloride test lasts eight hours and does not require blood testing, it can be unpleasant for some patients, because gastric irritation, nausea, and vomiting are common. Walsh and associates [4] showed that simultaneous administration of furosemide (to increase distal tubular sodium delivery) and fludrocortisone (to enhance principal cell sodium reabsorption and alpha intercalated cell hydrogen ion secretion) provided a sufficient and consistent stimulus to unmask an acidification defect in distal renal tubular acidosis, without the need for ammonium chloride. Simultaneous administration of furosemide and fludrocortisone provided an easy, effective, and well-tolerated alternative to the standard ammonium chloride urinary acidification test for the diagnosis of distal renal tubular acidosis. Following administration of furosemide $(40 \mathrm{mg}$ ) and fludrocortisone $(1 \mathrm{mg})$, the urine $\mathrm{pH}$ decreased to less than 5.3 in all healthy volunteers whereas all patients with previously diagnosed distal renal tubular aciodosis failed to acidify their urine to $\mathrm{pH}$ less than 5.3. Ammonium chloride test and furosemide/fludrocortisone test assess urinary acidification in different ways: the former by providing an acid load for the distal nephron to excrete and the latter by producing direct and indirect stimulation of distal nephron hydrogen ion secretion.

When calcium phosphate calculi, which are rare, are found in urinary bladder, it is advisable to exclude complete or incomplete renal tubular acidosis type 1 . In case a patient has renal tubular acidosis, it is possible to reduce the risk of recurrence of calcium phosphate stones by increasing citrate intake or taking vegetable and fruit rich diet. [5]

Spinal cord injury patients, who have indwelling catheters and develop vesical calculi, present with catheter blockages and urine infections. This patient was performing intermittent catheterisations and developed calcium phosphate stones in urinary bladder. The initial presenting symptom of vesical calculi in this patient was abdominal spasms. Doctors caring for spinal cord injury patients should be aware of the unusual symptoms, which are seen in spinal cord injury patients with various diseases. Hyperhidrosis may be the presenting symptom of renal calculi in a patient with spinal cord injury. [6]

This case raises an important question to which we do not have an answer. 
Table 3: Results of urine microbiology

\begin{tabular}{|c|c|c|}
\hline Date & Bacteria grown from culture of urine & Clinical symptoms \\
\hline 27 September 1992 & Enterococcus faecalis & Persistent fever despite gentamicin \\
\hline 07 June 1999 & Klebsiella aerogenes & Cold flushes down the back \\
\hline 22 September 1999 & Klebsiella aerogenes & Smelly urine \\
\hline 0I June 2000 & Pseudomonas aeruginosa & Feeling unwell \\
\hline 22 March 2005 & Escherichia coli & Abdominal spasms \\
\hline 16 August 2005 & Escherichia coli & Abdominal spasms \\
\hline 07 November 2005 & Klebsiella aerogenes and Escherichia coli & Pre-operative assessment \\
\hline I4 November 2005 & Klebsiella aerogenes and Escherichia coli & Pre-operative assessment \\
\hline 19 January 2006 & Enterococcus faecalis & Spasms in stomach \\
\hline 04 August 2006 & Pseudomonas aeruginosa and Enterococcus faecalis & Increased spasms \\
\hline 03 November 2006 & Enterococcus species and Pseudomonas species & Pre-operative assessment \\
\hline I4 May 2007 & Escherichia coli and Enterococcus faecalis & Pre-operative assessment \\
\hline 29 October 2007 & Escherichia coli and Enterococcus faecalis & Pre-operative assessment \\
\hline 19 March 2008 & Escherichia coli and Enterococcus faecalis & Pre-operative assessment \\
\hline 07 April 2008 & Escherichia coli & Pre-operative assessment \\
\hline 23 June 2008 & Escherichia coli & Pre-operative assessment \\
\hline
\end{tabular}

Table 4: Results of urine acidification test: furosemide $\mathbf{4 0} \mathrm{mg}$ and fludrocortisone $\mathrm{I} \mathbf{m g}$ were administered by mouth at 1000 hours

\begin{tabular}{|c|c|c|c|c|}
\hline Time (hours) & Urine pH & Urine Sodium (mmol/L) & Urine Potassium (mmol/L) & Urine Urea (mmol/L) \\
\hline 0945 & 6.3 & 31 & 20 & 85 \\
\hline 1100 & 6.0 & 106 & 36 & 85 \\
\hline 1200 & 6.3 & 74 & 22 & 23 \\
\hline 1300 & 5.7 & 47 & 21 & 21 \\
\hline 1400 & 5.56 & 49 & 35 & 44 \\
\hline 1500 & 7.4 & 23 & 135 & 150 \\
\hline 1600 & 7.5 & 16 & 161 & 212 \\
\hline
\end{tabular}

, Why did this patient with incomplete renal tubular acidosis develop calcium phosphate stones in urinary bladder and not in the kidneys?

We shall submit a follow-up of this patient after 18 months to inform the readers whether the diet rich in vegetables and fruits has been useful in preventing recurrence of calcium phosphate stones in urinary bladder.

\section{Conclusion}

We learn from this case that abdominal spasms may be the presenting feature of calcium phosphate stones in urinary bladder of spinal cord injury patients, as these stones, unlike magnesium ammonium phosphate stones, are not associated with recurrent urine infections. It is advisable to send specimens of stones removed from urinary bladder for biochemical analysis. If the major component of vesical calculus is found to be calcium phosphate, complete or incomplete renal tubular acidosis type 1 should be excluded, as it may be possible to reduce the risk of recurrence of calcium phosphate stones by oral potassium citrate therapy or vegetable and fruit rich diet.

\section{Consent}

Written informed consent was obtained from the patient for publication of this case report and accompanying images. A copy of the written consent is available for review by the Editor-in-Chief of this journal.

\section{Competing interests}

The authors declare that they have no competing interests.

\section{Authors' contributions}

SV developed the concept and wrote the draft. IW supervised biochemistry investigations. All authors contributed to patient care.

\section{Acknowledgements}

The authors are grateful to Mr Jamie Barr, Dantec Dynamics Limited, Garonor Way, Royal Portbury, Bristol, BS20 7XE, United Kingdom for making a payment of $£ 99$ plus VAT towards article processing fee for this manuscript.

\section{References}

I. DeVivo MJ, Fine PR, Cutter GR, Maetz HM: The risk of bladder calculi in patients with spinal cord injuries. Arch Intern Med 1985, 145(3):428-30. 
2. Haleblian GE, Leitao VA, Pierre SA, Robinson MR, Albala DM, Ribeiro AA, Preminger GM: Assessment of citrate concentrations in citrus fruit-based juices and beverages: implications for management of hypocitraturic nephrolithiasis. J Endourol 2008, 22(6): I359-66.

3. Hung EW, Darouiche RO, Trautner BW: Proteus bacteriuria is associated with significant morbidity in spinal cord injury. Spinal Cord 2007, 45(9):616-20.

4. Walsh SB, Shirley DG, Wrong OM, Unwin RJ: Urinary acidification assessed by simultaneous furosemide and fludrocortisone treatment: an alternative to ammonium chloride. Kidney Int 2007, 7 I (I2):|3|0-6.

5. Meschi T, Maggiore U, Fiaccadori E, Schianchi T, Bosi S, Adorni G, Ridolo E, Guerra A, Allegri F, Novarini A, Borghi L: The effect of fruits and vegetables on urinary stone risk factors. Kidney Int 2004, 66(6):2402-10.

6. Borawski KM, Sur RL, Preminger GM: Renal calculi presenting as hyperhidrosis in patient with spinal cord injury. Urology 2006, 67(5):el3-4.

Publish with Bio Med Central and every scientist can read your work free of charge

"BioMed Central will be the most significant development for disseminating the results of biomedical research in our lifetime. "

Sir Paul Nurse, Cancer Research UK

Your research papers will be:

- available free of charge to the entire biomedical community

- peer reviewed and published immediately upon acceptance

- cited in PubMed and archived on PubMed Central

- yours - you keep the copyright

Submit your manuscript here:

http://www.biomedcentral.com/info/publishing_adv.asp 